\title{
УТИЦАЈ РАЗГОВОРНОГ ЈЕЗИКА НА ТЕКСТОВЕ ПОПУЛАРНЕ НАУКЕ**
}

\begin{abstract}
У овом раду разматра се утицај разговорног језика на текстове популарне науке, а истраживање се спроводи на корпусу који чине (1) штампане публикације и (2) текстови са интернета. Циљ је да се са функционалностилистичког аспекта испита које су одлике разговорног језика заступљене у популарнонаучној литератури и које функције обавља овај идиом. Анализа је показала да заједничке одлике свих анализираних текстова јесу експресивност и аутоматизација у споразумевању. Аутори се ослањају на експресивна средства којима се служи свакодневна комуникација: (1) лексика којом се исказује субјективна оцена, (2) фраземи, (3) говорне фигуре, (4) узвичне реченице, (5) директно обраћање. Закључује се да разговорни језик има следеће функције у текстовима популарне науке: (1) да заинтересује читаоца и да га мотивише да прочита текст; (2) да оствари интеракцију са читаоцем; (3) да апстрактне садржаје науке конкретизује и приближи реципијентима изван струке.

Кључне речи: популарна наука, текст, разговорни језик, експресивност, аутоматизација, језичко-стилско средство.
\end{abstract}

\section{1. Увод}

У области популарнонаучне литературе данас постоји изразита хиперпродукција, а публикације се могу посматрати као производи који на тржишту траже пут до купаца. ${ }^{1}$ Очекивано је (1) да ће аутор, који је стручно лице, настојати да свој језички израз прилагоди читаоцима изван струке, и (2) да се за такво прилагођавање као погодно средство може употребити разговорни језик. ${ }^{2}$

\footnotetext{
*milkanik75@gmail.com

** Овај рад написан је у оквиру пројекта Динамика структура савременог српског језика (2011-2019), број 178014, који финансира Министарство просвете, науке и технолошког развоја Републике Србије.

${ }^{1}$ Један читалачки коментар показује каква су очекивања реципијената: „Naslovi i sadržaji vašeg naučno-popularnog časopisa na jednostavan i nestručnjacima zanimljiv način opisuju otkrića i događaje iz područja nauke" (http://www.astronomija.org).

${ }^{2}$ Наводимо коментар аутора из предговора једне од књига сврстаних у наш корпус: „Ова књига написана је једноставним и разумљивим језиком и самим тим прилагођена је широј чи-
} 
У овом раду се разматра утицај разговорног језика на текстове популарне науке, а истраживање се спроводи на корпусу који чине (1) штампане публикације (књиге), као и (2) текстови са интернета (чланци на сајтовима популарне науке). ${ }^{3}$ Циљ је да се са функционалностилистичког аспекта испита: (1) које су одлике разговорног језика заступљене у популарнонаучној литератури; (2) које функције обавља овај идиом.

Поставља се питање функционалног (под)стила којим су писани текстови популарне науке. Према традиционалној класификацији, научно-nonyларни подстил припада научном стилу, у који се још сврставају и академски (строго научни) и уцбенички подстил (Тошовић 2002: 330). Ови подстилови се разликују: (1) према циљу општења (професионални, образовни, „приватни" циљ); (2) према учесницима комуникације, при чему је пошиљалац информације увек научник/стручњак, док се прималац разликује (научник/ стручњак, ученик, лице изван струке). С друге стране, поједини проучаваоци везују популарну науку за посебан функционални стил, који има одлике и научног и медијског дискурса (Катнић Бакаршић 2001: 174-176).

У нашем корпусу, који смо према циљу и учесницима комуникације сврстали у популарну науку, овом приликом испитујемо заступљеност и функцију елемената разговорног језика. За другу прилику остављамо испитивање заступљености језичко-стилских одлика научног стила, с једне, и публицистичког, с друге стране, будући да та тема захтева посебан простор за разматрање.

\section{2. Приступ проблему}

Појам разговорни језик успоставља сложене везе са више појмова: (1) говорени језик, говорни језик, усмени језик/говор, односно писани језик, писмени језик/говор; (2) разговорни стил, колоквијални језик/стил, фамилијарни језик/стил односно књижевни језик/говор/стил (в. Кликовац 2008). Чланови овог појмовно-терминолошког скупа припадају различитим лингвистичким школама (Кликовац 2008: 148), а обједињени су критеријумом медијума у којем се језик остварује (говор - писање). ${ }^{4}$ За диференцијацију појма разговорни језик од њему сродних појмова значајно је више параметара који се тичу употребе језика: (1) област људске делатности и тематика - од свакодневног живота са његовим уобичајеним темама до јавног живота, културе, науке итд. са разноврсним темама; (2) врста ситуације - од фамилијарне до формалне; (3) начин реализације - дијалошки или монолошки; (4) правил-

талачкој публици. Поједини делови обрађених тема изискују употребу стручних израза, који нису могли бити избегнути, а који читањем комплетног текста постају јасни" (Канцеер је могуће спречити, 10).

${ }^{3}$ У складу с предвиђеним обимом рада, изван корпуса остају: (1) популарнонаучне публикације намењене и прилагођене ученицима; (2) популарнонаучни текстови у новинама (који нису написани од стране стручњака, него од стране новинара).

${ }^{4} \mathrm{O}$ језичким варијететима издвојеним према критеријуму медијума у којем се остварују (говор и писање), в. Кликовац 2008; Савић 1993: 47-50. 
ност језика - стандарднојезички или супстандардни варијетет (Кликовац 2008: 147-148).

Разговорни језик јесте ,јјезик неформалних разговора” (Кликовац 2008: 157), самим тим, „он има различите одлике (фонетске, лексичке, граматичке) које ће истаћи такву његову природу и које могу бити и супстандардне" (Кликовац 2008: 164). Проучаваоци истичу да разговорни језик није једноставан феномен, као што ни свакодневни разговори нису увек тривијални (Милосављевић 2014: 51; Савић/Половина 1989: 2).

Разговорни језик као најраспрострањенији вид неформалног свакодневног језика појављује се и у популарнонаучној литератури. Аутори настоје да остваре интеракцију са читаоцем (слично као у свакодневној конверзацији), ${ }^{5}$ и да ширем кругу читалаца приближе садржај свог текста користећи поједине одлике разговорног језика (нпр. разговорна лексика, устаљени изрази). ${ }^{6}$

Разговорни језик има „одређени аутоматизовани део”, стереотипе и формуле, језичке игре, које немају други начини општења, а с друге стране, у њему постоји „далеко више могућности за реализацију креативног начела, [...], што значи одређену стилску отвореност и идиолекатску слободу" (Савић/Половина 1989: 5). Наведене особине запажају се и у употреби елемената разговорног језика у нашем корпусу.

У досадашњој србистичкој литератури постоји ослонац од којег се може поћи у истраживањима разговорног језика - почев од теоријских промишљања овог феномена (Кликовац 2008; Лубаш 2004; Симић 1995), преко истраживања која су спроведена на ширем корпусу с циљем да се обухватније сагледају одлике разговорног језика (Кликовац 2008; Половина 1987; Поповић 2004; Савић/Половина 1989), до ужих истраживања у којима се испитују одређене одлике овог идиома (Бјелогрлић 2015; Милосављевић 2016; Половина 1986; Половина/Панић Церовски 2013). Проучавоци су се бавили и појединим аспектима разговорног језика, као што су нормативни (Ристић 2006) и дидактички (Стевић 2007), а њима ћамо придружити и ауторе који су са стилистичког аспеката обухватили разговорну лексику (Голубовић 2009; Мишић 2016).

\section{3. Разултати анализе}

На основу високих тиража и бројних наслова домаћих и страних (преведених) публикација, запажа се да преокупацију савременог човека у популарној науци представљају следеће области: природа, свемир, здравље и успех. Учесници комуникације немају исте циљеве у овим областима. Текстови нашег корпуса могу се разврстати у две групе, зависно од циља комуникације између пошиљаоца и примаоца:

(a) Занимљива наука - обухвата астрономију и природне науке. Посматрано из перспективе аутора, циљ је да се пренесу актуелне

\footnotetext{
${ }^{5}$ Конверзација предстаља „интеракцијску активност”, в. Стевић 1997: 18.

${ }^{6} \mathrm{O}$ појму разговорне лексике и критеријумима њеног издвајања, в. Ристић 2006: 55-58.
} 
научне информације и да се читаоцу омогући да ужива не само у сазнавању него у читању интересантног текста.

(б) Примењена наука - обухвата медицину и психологију. Циљ је да се читаоцу пруже примењива знања, при чему примењивост заузима водеће место у односу на информативност и читалачко уживање.

При интерпретацији резултата анализе треба узети у обзир обим текста и медиј у коме је текст остварен:

(a) Занимљива наука - остварује се у краћим текстовима (чланцима) на интернету, а читаоцима овај медиј омогућава да комуницирају с ауторима. Дакле, мање је простора, а мање је и потребе да се у самом чланку користе одлике разговорног језика.

(б) Примењена наука - остварује се у књигама које захтевају дуготрајније читаочево дружење с текстом. Интеракција учесника комуникације није директно остварива, па се надокнађује у тексту појачаном употребом разговорног језика.

Заједничка одлика корпуса у целини јесте емоционално-експресивна обојеност и уопште употреба маркираних (као и неутралних) језичких ресурса, а то су типичне одлике свакодневне комуникације (Симић/Јовановић 2002: 239). ${ }^{7}$

Анализа је потврдила наше очекивање о утицају разговорног језика на текстове популарне науке. Разултате анализе изложићемо посебно за два дела корпуса која смо претходно издвојили.

\section{1. Занимљива наука}

Аутори овог дела корпуса употребљавају разговорни језик при обликовању интересантног и допадљивог израза, чиме одржавају читаочеву пажњу и подстичу његову мотивацију да прати текст. Ево карактеристичних примера: ${ }^{8}$

(1) Kao što sam rekao, uz dobru promociju i marketing, ali i mogućnost za jednostavan ulazak u postupak trgovanja, na tržištu ove robe (programi i aplikacije za trgovanje kriptovalutama) sve veći broj ljudi je hteo da dođe do svog malog bogatstva, a da pritom ne mora mnogo da radi, ili narodski rečeno hoće hleb bez motike (Свет науке).

(2) Koliko može da košta izgradnja ,jednostavnog" raketnog servisnog tornja? Pa, ako govorimo o Nasinoj budućoj raketi SLS, cena može da dostigne i milijardu dolara. Kako ti se čini cifra? Nema šale - istina jе (Астрономија).

(3) Ovo vam je verovatno bilo poznato, ali pitate se možda zašto je baš današnji dan bitan za broj $\pi$ ? Razlog za to je činjenica da $u$ Velikoj Britaniji ne samo što voze levom stranom ulice, već i mnoge druge stvari čine drugačije od ostalih (Свет науке).

(4) Pogledajte ovu fotografiju Meseca i Zemlje, napravljena je prošlog oktobra sa DSLWP-B. Neviđena slika! Nažalost, slike pomračenja će najverovatnije biti labudova pesma za DSLWP-B: očekuje se da će mali satelit pasti na drugu stranu Meseca [...] (Астрономија).

${ }^{7}$ О појму и начинима вербализације експресивности, в. Јовановић 2005; Јовановић 2007a; Јовановић Симић 2016. О експресивности у различитим стиловима, в. Јовановић 2007б; Јовановић 2010.

${ }^{8}$ Курзивом истичемо делове текста у којима се запажа утицај разговорног језика. 
(5) Kad sam bio mali i išao u neke osnovne škole, čuo sam da postoje neimenovana „primitivna plemena" koja imaju reči za količine kao što su jedan, dva, tri, a za svaki veći broj se uhvate za kosu - što im je bio znak za „mnogo”, otprilike toliko koliko vlasi kose obuhvate šakama. Ja sam bio zgranut, ne verujući da ti ljudi nisu u stanju da prebroje 4 noge kod neke životinje, ili 10 prstiju na svojim rukama, ali sam ćutao jer se u to vreme nezgodna pitanja u školi nisu postavljala. Naravno, mi, klasno svesni, smo znali šta znači 10 ili 100 ili 1000 ili... ili... koliko? Mnogo. Na primer, kasnije smo standardno baratali brojevima kao što su 500 milijardi od koje su se ljudi za kosu hvatali, ali su novčanicu normalno koristili (Астрономија).

(6) Ali zašto se uopšte pojavila priča o sodi bikarboni bez aluminijuma? Zato što se prvo pojavila teorija zavere o tome da farmaceutska mafija krije od ljudi širok spektar blagotvornih dejstva sode bikarbone, jer želi da proda svoje skupe lekove koji često i ne leče ništa. Aha... Znači žele da se obogate na tuđoj nesreći! Čekajte, ali onda se pojavio još neko ko se dosetio da „običnu” sodu bikarbonu proglasi štetnom, i da ,terapijski efekat ima samo medicinska soda bikarbona bez aluminijuma”. Hт... To mora da je neka ,sodobikarbonska” mafija!? (Свет науке).

(7) Broj g1 je zaista veliki, ali moguće je zapisati i sledeći, veći. Broj g2 se ne dobija pomoću 5 strelica. Ne, broj g2 se dobija kada upišemo g1 strelica između trojki. Ali, to je nemoguće zapisati niti izračunati! Pa, zapisaćemo ga ovako g2=3g13, gde g1 označava broj strelica između trojki. Wow! Aha, ali ovo može i da se nastavi! Uvedimo broj g3=3g23. Znači, taj smešno mali broj g2 označava broj strelica kod definicije broja g3, a on nam samo služi da definišemo broj g4. Ima li kraja ovom ludilu, i šta je nas cilj? Odgovor-ima. Ovakvim postupkom dolazimo do broja g64. E, taj broj nam treba i on se zove Grahamov broj (Астрономија).

Хумор представља један од начина да се допринесе не само занимљивости текста, него и интеракцији са читаоцем (у Великој Британији не само цто возе левом страном улице, већ и многе друге ствари чине другачије од осталих; ћутао [сам] јер се у то време незгодна питања у школи нису постављала). Наиме, хумор поразумева да прималац сарађује с пошиљаоцем тако што покушава да препозна и протумачи хумористички стилизован исказ.

У избору и комбиновању лексике аутори се опредељују за изразе који стилски нису погодни за текст којим се преносе научни садржаји (содабикарбонска мафија; смешно мали број; народски речено хоће хлеб без мотике; желе да се обогате на туђој несрећи). Стилски снижен начин изражавања посебно се запажа у почетним и завршним деловима текста, када аутор отвара и затвара комуникацију (одломци које наводимо налазе се већином на почетку или на крају чланака).

Јављају се следеће одлике: (1) експресивна лексика (згранут); (2) фраземи (лабудова песма); (3) стилске фигуре препознатљиве читаоцу (таутологија: Нема шале - истина је; елипса: Одговор - има; хипербола: Али, то је немогуће записати); (4) употреба интензификатора (баш данашьи дан); (5) упитне реченице (Али зашто се уопште појавила прича [...]?); (6) узвичне реченице (Невиђена слика!); (7) директно обраћање, које је чешће у другом лицу множине (Погледајте ову фотографију), ређе у другом лицу једнине (Како ти се чини цифрра?); (8) контекстуална елипаса ([...] колико? Много); (9) аутор се експлицитно укључује у текст, говори у првом лицу једнине и настоји да постигне индивидуалност израза (примери 1 и 5). 


\section{2. Примењена наука}

У овом делу корпуса запажа се изразита укљученост говорника у текст, која се испољава у говорниковом исказивању личног става, у његовој усмерености на међуљудски однос, као и у његовом настојању да свој (монолошки) говор језички обликује као дијалог са читаоцем. Наводимо карактеристичне примере:

(8) [...] могу само рећи да су неки од њих познати широј јавности, док се други могу сврстати у оно што се зове „обични смртнищи”: возачи, пекари, кројачи, продавци. [...] И баш зато што су се дизали кад би већина остајала да лежи оплакујући сопствени пораз и јер су били убеђени да ће успети, зато су и успели. [...] Кроз низ систематизовано постављених правила, којима ћете „набилдовати” сопствено самопоуздање, „очистити” ум од најгорих токсина који су у њему, а то су рђаве мисли, гарантујем да ћете поново дисати пуним плућима. [...] Зато, крећемо! (Моћ жеље, 18-19).

(9) Када наш имуни систем ради пуном паром? Наш имуни систем је у пуној снази када нисмо склони инфекцијама [...] (Каниер је могуће спречити, 17).

(10) Студије су показале да припрема хране у микроталасној рерни директно скраћује животни век и доприноси развоју тумора. Зато памет у главу! (Темељи здраве исхране, 69)

(11) Цмиздравци, кукумавчила, жртве [изрази којима су аутори ове књиге назвали психолошке типове неуспешних особа]. Препознаћете их по томе што су суморни до бола. Кад год их сретнете, они имају неку „сестро слатка” или „брате мили” муку да вам испричају и изјадају се. Муку за коју нису криви, већ им се дешава туђом кривицом (Живети или животарити, 65).

(12) Психопате, контролори, крокодили [изрази којима су названи типови неуспешних особа]. Психопате су гадни играчи. [...] Ако вас при томе повреде, баш их брига. Циљ оправдава средство, а ви сте само „колатарална штета". Потрудиће се да прикажу како су, у ствари, направили нешто велико и племенито. Како су били „милосрдни анђели”. Кад вас потроше, наћи ће замену. Кога нема без њега се може. Алави су до крајности. Крокодили су „мала беба" за њих (Живети или животарити, 65).

(13) Разуверавање пргавиа људи доживљавају као јалов посао. Ко ће да се бакће са будалом која све искривљује и у свему види разлог за свађу (Живети или животарити, 67).

(14) Ако сте ној, и не желите чак ни да видите да имате проблем, напор да вам се помогне је „ћорав посао” јер сте сами „ћорави” за своје проблеме. Зашто би се неко трудио да вам помогне, када ви сами то не чините за себе (Живети или животарити, 74).

(15) Како ви одговарате када вас питају како живите? Како бисте искрено одговорили на то питање? Да ли живите или животарите? Да ли сте ви успешни? Неко од вас ће рећи нешто као: „Успешни у чему? Зависи од тога шта сматрате успехом, како дефинишете успех..." Шта ви сматрате успехом? У чему сте успешни? Да ли сте успешни ако успех дефинишемо овако: успех је реализација оних циљева које смо поставили пред себе? (Живети или животарити, 5)

(16) [...] ако би вам неко рекао да је успешан у каријери, али је његов брак тотална пропаст? Да ли је тај човек успешан? Или, неко је познат, велико име, а дете му се дрогира? Има оних који ће рећи: „Па не може човек да успе у свему, у свим важним аспектима живота, не може да има баш све добро. И каријеру, и новац, и породицу, и пријатеље, и здравље.” То је велика заблуда. Лажу вас. Човек може да буде успешан у свему, и једино је тада успешан, Може ако хоће. Можда ће неко рећи да је то могуће негде на другом месту, али не и овде, у Србији (чули смо доста таквих коментара). Глупост. Може ако хоће и ако зна како (Живети или животарити, 6).

Како показују примери, језички израз се на лексичком плану у великој мери приближава свакодневној неформалној комуникацији. У овим публикацијама мање се употребљава уже стручна терминологија, а више се користе 
„изрази о чијем значењу постоји прећутни консензус у читавој културно-језичкој заједници” (Ђорић Француски/Ракић 2015: 75).

Различити видови конкретизације израза и снижене стилске тоналности у великој су мери заступљени у овом делу корпуса. Издвајају се следеће одлике: (1) стилски маркирани изрази којима се исказује субјективна оцена (имиздравац, кукумавчило, будала; ћорав посао; гадан играч; алав до крајности); (2) фраземи (дисати пуним плућима), паремије (Циљ оправдава средство) и други типови устаљених израза (обични смртници; колатерална штета); (3) стилске фигуре (метафора: „очистити” ум од најгорих токсина [тј. од рђавих мисли]; плеоназам: мала беба; иронија: Муку за коју нису криви, већ им се дешава тућом кривицом; реторичко питање: Ко ће да се бакће са будалом $[. .]$.$) ; (4) употреба интензификатора (баш све добро); (5) форме директног об-$ раћања (Да ли сте ви успешни?); (6) узвичне реченице (Зато памет у главу!); (7) упитне форме, при чему се често јавља више питања у низу (примери 15 и 16); (8) аутор говори у првом лицу једнине (гарантујем да [...]), а множина се употребљава ако има више аутора (чули смо [...]); (9) понављање које доприноси текстуалној кохезији, као и истицању делова текста (речи ycnex и успешан у примерима 15 и 16); (10) навођење туђих речи, при чему аутор отворено исказује негативан став према туђем мишљењу (примери 15 и 16).

\section{3. Завршни осврт на разултате анализе}

Заједничке одлике свих анализираних текстова јесу експресивност и аутоматизација у споразумевању. Употребљавају се: (1) јединице са системском (инхерентном) експресивношћу, које доприносе аутоматизацији и економичности комуникације, будући да су познате говорницима српског језика; (2) јединице с контекстуалном (адхерентном) експресивношћу, при чему и у овом случају аутори бирају општепознате поступке, дакле, не тежи се дезаутоматизацији, онеобичавању, тзв. отежаној форми.

Аутори се ослањају на експресивна средства којима се служи свакодневна комуникација: (1) лексика којом се исказује субјективна оцена; ${ }^{9}$ (2) фраземи; ${ }^{10}$ (3) говорне фигуре (метафора, плеоназам, таутологија, елипса, иронија, хипербола, реторичко питање); ${ }^{11}$ (4) узвичне реченице, ${ }^{12}$ (5) директно обраћање (у другом лицу). ${ }^{13}$

\footnotetext{
9 Лексика којом се исказује субјективна оцена јесте разноврсна у погледу лескичко-семантичких и творбених особина. О експресивности у лексици, в. Ристић 2004.

${ }^{10}$ Фраземи у језику функционишу „управо као јединице које врше утицај на адресата” и могу се сматрати „идеалним прагмемама” (Пејановић 2016: 362).

${ }^{11}$ Говорне фигуре представљају изразито субјективни чин (њима се изражава говорников емотивни став) и подразумевају интерактивност: потребан је „сараднички однос” између пошиљаоца и примаоца да би се говорна фигура „енкодирала и декодирала на жељени начин” (Милосављевић 2016: 308-309).

${ }^{12}$ Категоријална одлика узвичних реченица јесте „експресивност, схваћена као афективност, као израз емоционалног става говорника" према садржају пропозиције и према саговорнику (Бабић 2016: 264).

${ }^{13}$ Друго лице је конкретније од првог и трећег лица (Тошовић 2002: 351).
} 
Корпус популарне науке одликује се и увођењем начина комуникације карактеристичног за приватну сферу живота. Како показују истраживања, „у модерном друштву све више слаби граница између приватне и јавне употребе језика" (Вељковић 2016: 300). ${ }^{14}$ Интерференција кодова јавне и приватне комуникације запажа се и у популарнонаучној литератури: аутори одустају од ,језичне 'ексклузивности' јавног комуницирања" (Шкиљан 1998: 24) и окрећу се језичким средствима из приватног домена, самим тим и разговорном језику.

\section{4. Закључак}

У корпусу популарне науке који је обухватио текстове из области природних наука, астрономије, медицине и психологије - запажа се утицај разговорног језика.

Стварајући у контексту савременог медијског окружења и под притиском хиперпродукције која постоји у данашњој популарнонаучној литератури, аутор улаже много креативног напора да освоји читаоца. Разговорни језик у томе има значајну улогу. Његове су функције: (1) да заинтересује читаоца и да га мотивише да прочита текст; (2) да оствари интеракцију са читаоцем; (3) да апстрактне садржаје науке конкретизује и приближи реципијентима изван струке.

Аутор се обраћа читаоцу, разговара с њим, настоји да успостави неформалну атмосферу и да изађе из оквира институционализоване комуникације (која постоји у науци и медијима). Заједничка одлика корпуса у целини јесте употреба експресивних средстава, којима се служи свакодневна комуникација.

Популарнонаучне текстове објављене на интернету треба посебно посматрати. Интернет представља, да тако кажемо, неограничен простор за објављивање, самим тим аутори су принуђени да трагају за начинима којима ће задржати читаоце на свом тексту, што доприноси увођењу разговорног језика у популарну науку.

Тенденција приближавања кодова јавне и приватне комуникације, карактеристична за савремено друштво, одражава се и на популарну науку, која са своје стране томе доприноси јер аутори трагају за формама које су употребљиве у оба домена.

\footnotetext{
${ }^{14}$ Средства јавног информисања „све [се] више отварају према језичким средствима карактеристичним за домен приватне употребе језика, исто као што елементи језика јавне речи продиру у домен приватног” (Вељковић 2016: 300). Комуникација на друштвеним мрежама (на интернету) отворила је пут уласку језика свакодневне неформалне комуникације у јавни простор (уп. Вилчек 2014).
} 


\section{ИЗВОРИ}

Астрономски магазин: http://www.astronomija.org. 11. 08. 2019.

Живети или жсивотарити: Н. Јовановић, Т. Фиревски Јовановић, С. Јовановић, Живети или животарити, Београд: Народна књига, 2006.

Канцер је могуће спречити: М. Матић, Канщер је могуће спречити, Београд: Агенција „Матић”, 2013.

Моћ жељь: 3. Карановић, Моћ жеље: водич за животни оптимизам, Београд: Лагуна, 2013.

Свет науке: https://www.svetnauke.org. 11. 08. 2019.

темељи здраве исхране: И. Вукић, Темељи здраве исхране, Ниш: МБ „Графика", 2008.

\section{ЛИТЕРАТУРА}

Бабић 2016: М. Бабић, Комуникативни и експресивни модели екскламативних реченица у српском језику, Научни састанак слависта у Вукове дане, 45/1, 263-273.

Бјелогрлић 2015: A. Bjelogrlić, Novi(ji) kvotativi u razgovornom diskursu savremenog srpskog jezika, Радови Филозофског факултета, 17, Источно Сарајево, 65-85.

Вељковић 2016: Д. Вељковић, Употреба разговорног стила у српским штампаним медијима, $y$ : М. Ковачевић, Ј. Петковић (ур.), Српски језик, књижевност, уметност, књ. 1, Језик, књижевност, уметности, Крагујевац: ФИЛУМ, 295-308.

Вилчек 2014: D. Vilček, Čujemo se Fejsom: o razgovornom stilu na Facebooku (s posebnim osvrtom na leksičku razinu), Hrvatistika, 7, Osijek, 95-104.

Голубовић 2009: Б. Голубовић, Употреба нестандардне лексике у светлу савремених друштвених кретања на примеру новинског стила српске штампе, $y$ : М. Ковачевић (ур.), Српски језик, кюижевност, уметност, књ. 1, Српски језик у употреби, Крагујевац: ФИЛУМ, 141-160.

Ђорић Француски/Ракић 2015: B. Đorić Francuski, J. Rakić, Da li je sreća lepa samo dok se čeka ili je svako kovač svoje sreće, $y$ : Д. Бошковић (ур.), Срећа, Крагујевац: ФИЛУМ, 13-30.

Јовановић 2005: Ј. Јовановић, Неколико запажања о појмовној дисперзији термина 'експресивност' и њему сродних, Научни састанак слависта у Вукове дане, 34/3, 227-236.

Јовановић 2007а: Ј. Јовановић, О експресивним стилизацијским средствима у Дучићевом есејистичком стилу, Узданииа, V/1, Јагодина, 1-31.

Јовановић 2007б: Ј. Јовановић, 'Реченична експресивност' са становишта синтаксе и стилистике (теоријско-терминолошки приступ), Наслеђе, 6, Крагујевац, 55-74.

Јовановић 2010: Ј. Јовановић, Средства експресивизације у новинском тексту, Научни састанак слависта у Вукове дане, 39/3, 135-156. 
Јовановић Симић 2016: Ј. Јовановић Симић, Начини вербализације експресивности (према грађи из романа Чедомир Илић М. Ускоковића), Научни састанак слависта у Вукове дане, 45/1, Београд: МСЦ, 237-251.

Кликовац 2008: D. Klikovac, O jezičkim varijetetima nastalim prema medijumu (govor - pisanje), u: D. Klikovac, Jezik i moć, Beograd: Biblioteka XX vek, $147-185$.

Катнић Бакаршић 2001: M. Katnić-Bakaršić, Stilistika, Sarajevo: Naučna i univerzitetska knjiga.

Лубаш 2004: W. Lubas, Две врсте стандарда у словенским језицима, Научни састанак слависта у Вукове дане, 33/1, 5-14.

Милосављевић 2014: Б. Милосављевић, Оговарање као говорни жанр свакодневне комуникације, Београд: Институт за српски језик САНУ.

Милосављевић 2016: Б. Милосављевић, Хипербола у говору свакодневне комуникације (семантичко-прагматички приступ), Научни састанак слависта у Вукове дане, 45/1, 301-311.

Мишић 2016: Б. Мишић, Доминантни типови колоквијалне лексике у прози Мома Капора, y: М. Летић (ур.), Наука и евроинтеграције, 10/2, Источно Сарајево: Филозофски факултет, 47-54.

Пејановић 2016: А. Пејановић, Експресивност као категоријална особина фразеолошких јединица, Научни састанак слависта у Вукове дане, 45/1, 361-367.

Половина 1986: В. Половина, Зависне узрочне реченице у разговорном српскохрватском језику, Научни састанак слависта у Вукове дане, 15/1, 85-93.

Половина 1987: V. Polovina, Leksičko-semantička kohezija u razgovornom jezi$k u$, Beograd: Filološki fakultet.

Половина/Панић Церовски 2013: В. Половина, Н. Панић Церовски, Функције апроксиматора у српском разговорном дискурсу, $y:$ М. Ковачевић (ур.), Српски језик, књижевност, уметност, књ. 1, Традиичја и иновације у српском језику, Крагујевац: ФИЛУМ, 157-168.

Поповић 2004: Љ. Поповић, Управни говор као грађа за лингвистичка истраживања, Научни састанак слависта у Вукове дане, 32/1, 55-77.

Ристић 2004: С. Ристић, Експресивност у језику и у лексичком систему, $y$ : С. Ристић, Експресивна лексика у српском језику, Београд: Институт за српски језик САНУ, 13-44.

Ристић 2006: С. Ристић, Нормирање лексике разговорног језика, $y$ : С. Ристић, Раслојеност лексике српског језика и лексичка норма, Београд: Институт за српски језик САНУ, 53-64.

Савић 1993: S. Savić, Diskurs analiza, Novi Sad: Filozofski fakultet.

Савић/Половина 1989: S. Savić, V. Polovina, Razgovorni srpskohrvatski jezik, Novi Sad: Filozofski fakultet.

Симић 1995: Р. Симић, Лингвистички статус разговорног језика односно колоквијалног стила, Научни састанак слависта у Вукове дане, 23/2, $5-17$. 
Симић/Јовановић 2002: Р. Симић, Ј. Јовановић Основи теорије функиионалних стилова, Београд: Научно друштво за неговање и проучавање српског језика, Никшић: Јасен.

Стевић 1997: S. Stević, Analiza konverzacije, Beograd: Filološki fakultet.

Стевић 2007: S. Stević, Italijanski razgovorni jezik kao izvor didaktičkog dijaloga, u: J. Vučo (ur.), Savremene tendencije u nastavi jezika i književnosti, Beograd: Filološki fakultet, 92-103.

Тошовић 2002: Б. Тошовић, Функциионални стилови, Београд: Београдска књига.

Шкиљан 1998: D. Škiljan: Javni jezik: pristup lingvistici javne komunikacije, Beograd: Biblioteka XX vek.

Milka V. Nikolić

THE INFLUENCE OF CONVERSATIONAL LANGUAGE ON POPULAR SCIENCE TEXTS

\section{Summary}

The subject of interest of this paper is popular scientific literature, whose authors are the experts in a particular field, while the readers do not belong to the field. It is expected for an author to strive to adjust the linguistic expression for the readers who have no expertise, and it is also expected that the appropriate instrument for the purpose could be conversational language. This paper discusses the influence of conversational language on popular science texts, and the research is conducted on the corpus of printed publications and texts from the internet (fields: natural sciences and psychology). The goal is to examine from the stylistic aspect: (1) which characteristics of conversational language are present in popular scientific literature; (2) which functions an idiom performs in popular science texts. The analysis has shown that the common characteristics of all analyzed texts are the expressiveness and automatization in communication. The authors rely on the expressive means used for everyday communication: (1) the lexis used by an author to express personal evaluation, (2) phrasemes, (3) figures of speech, (4) exclamatory sentences, (5) direct communication. It is concluded that an author, who creates in the context of contemporary printed and electronic media, puts a lot of creative effort to attract the readers' attention. Conversational language has an important role in all of that. Its functions are: (1) to pique a reader's interest and motivate the reader to read the text; (2) to make an interaction with the reader; (3) to verbalize and bring closer the abstract scientific contents to the recipients outside the domain. The tendency of bringing closer the public and private communication, common for modern society, reflects on popular science also, which contributes to it because the authors search for the linguistic forms that are used in both domains.

Keywords: popular science, text, conversational language, expressiveness, automatization, linguo-stylistic means. 